\title{
Coffea arabica bean extract inhibits glucose transport and disaccharidase activity in Caco-2 cells
}

\author{
ATCHARAPORN ONTAWONG ${ }^{1}$, ACHARAPORN DUANGJAI $^{1}$ and CHUTIMA SRIMAROENG ${ }^{2}$ \\ ${ }^{1}$ Division of Physiology, School of Medical Sciences, University of Phayao, Muang Phayao, Phayao 56000; \\ ${ }^{2}$ Department of Physiology, Faculty of Medicine, Chiang Mai University, Chiang Mai, Nong Khai 52000, Thailand
}

Received February 3, 2021; Accepted June 14, 2021

DOI: $10.3892 /$ br.2021.1449

\begin{abstract}
The major constituents of Coffea arabica (coffee), including caffeine, chlorogenic acid and caffeic acid, exhibit antihyperglycemic properties in in vitro and in vivo models. However, whether Coffea arabica bean extract (CBE) regulates glucose uptake activity and the underlying mechanisms involved remain unclear. The aim of the present study was to examine the effects of CBE on glucose absorption and identify the mechanisms involved using an in vitro model. The uptake of a fluorescent glucose analog into Caco-2 colorectal adenocarcinoma cells was determined. The expression levels of sodium glucose co-transporter 1 (SGLT1) and glucose transporter 2 (GLUT2) were evaluated. In addition, glycoside hydrolase enzyme activity was investigated. It was observed that $\mathrm{CBE}$ inhibited disaccharidase enzyme activity. Furthermore, CBE exerted an inhibitory effect on intestinal glucose absorption by downregulating SGLT1- and GLUT2-mediated 5' AMP-activated protein kinase phosphorylation and suppressing hepatocyte nuclear factor $1 \alpha$ expression. These data suggest that CBE may attenuate glucose absorption and may have potentially beneficial antihyperglycemic effects in the body; however, the mechanisms underlying the effects of CBE must be elucidated through further investigation.
\end{abstract}

\section{Introduction}

Type 2 diabetes is a disease that occurs when blood glucose levels are high, which is referred to as hyperglycemia. The severity of hyperglycemia is determined by an imbalance between glucose entering and leaving the circulation. Carbohydrates from the diet are hydrolyzed by digestive enzymes. $\alpha$-Glucosidase

Correspondence to: Dr Atcharaporn Ontawong, Division of Physiology, School of Medical Sciences, University of Phayao, 19 Moo 2 Mae-Ka, Muang Phayao, Phayao 56000, Thailand E-mail: atcharaporn.on@up.ac.th

Abbreviations: CBE, Coffea arabica bean extract; GLUT2, glucose transporter 2; SGLT1, sodium glucose co-transporter 1

Key words: CBE, 5' AMP-activated protein kinase, glucose uptake, GLUT2, hepatocyte nuclear factor $1 \alpha$, SGLT1 or sucrase-isomaltase cleaves the $\alpha$-glucoside bonds of disaccharides, including sucrose, to monosaccharides. The absorption of dietary monosaccharides by the intestine may be one of the risk factors associated with diabetes mellitus (1). Glucose derived from starch or sucrose is taken up by the epithelial cells through the brush border membrane (BBM), predominantly by a sodium-dependent glucose co-transporter (SGLT1) (2,3). A previous study has revealed that glucose transporter 2 (GLUT2) is expressed at the BBM of enterocytes during the digestive phase and may affect circulatory glucose concentration (2). Subsequently, glucose effluxes across the basolateral membrane (BLM) to the blood circulation via GLUT2. Therefore, any factor that influences the activity of SGLT1 and GLUT2 also alters the absorption and metabolism of glucose.

Previous studies have reported that intestinal SGLT1 mRNA expression is increased in streptozotocin-induced diabetic rats and mice (4,5). Additionally, Otsuka Long-Evans Tokushima Fatty rats exhibiting increased intestinal SGLT1 mRNA expression combined with impaired glucose tolerance ultimately developed insulin resistance and hyperinsulinemia (6). Similarly, patients with type 2 diabetes mellitus also exhibit elevated intestinal glucose uptake as a result of increased SGLT1 mRNA and protein expression (7). Furthermore, GLUT2 protein expression is increased at the BBM of enterocytes in streptozotocin-induced diabetic rats (8) and in response to elevated glucose levels in the intestinal lumen (9). Therefore, intestinal SGLT1 and GLUT2 have a significant impact on the progression of diabetes mellitus.

Coffea arabica is one of the most widely consumed beverages. In traditional Chinese medicine, the green Coffea bean is classified as a blood circulation warmer, liver qi (Chinese concept of energy) and menstrual regulation, stimulant, heart orifice opening, detoxification and tonification herb (a traditional Chinese medicine therapeutic concept that nourishes and replenishes the qi and blood of weakened individuals) (10). At present, the Coffea species C. arabica (Arabica) and C. canephora (Robusta) are economically important in the global coffee market. The major constituents of Coffea include caffeine, chlorogenic acid, diterpenes and trigonelline (11). Moderate intake of Coffea has been linked to a reduced risk of chronic diseases, including type 2 diabetes, Parkinson's disease and liver disease (12-14). As mentioned above, there are several studies on the antidiabetic potential of roast Coffea. However, to the best of our knowledge, the effects of Coffea arabica bean extract (CBE) on glucose absorption and the related mechanisms remain unknown. The 
aim of the present study was to examine the effects of $\mathrm{CBE}$ on glucose absorption in human Caco-2 colorectal adenocarcinoma cells. Additionally, the molecular mechanisms involved in glucose transport in an in vitro model were determined.

\section{Materials and methods}

Chemicals. DMEM/F12, CelLytic MT mammalian tissue lysis/extraction reagents, phloretin, chlorogenic acid, caffeine, caffeic acid and ferulic acid were purchased from Sigma-Aldrich; Merck KGaA. FBS was purchased from Gibco; Thermo Fisher Scientific, Inc. Polyclonal rabbit anti-SGLT1 (1:250; cat. no. 07-1417), GLUT2 (1:250; cat. no. 07-1402-I), 5' AMP-activated protein kinase (AMPK; 1:250; cat. no. 07-1417) and phospho-AMPK (1:250; cat. no. 07-363) were purchased from Merck KGaA. Monoclonal mouse alkaline phosphatase (ALP; 1:500; cat. no. NB110-3638) antibodies were obtained from Novus Biologicals, LLC. Monoclonal mouse anti- $\beta$-actin (1:500; cat. no. ab8224) was purchased from Abcam. 2-(N-(7-nitrobenz-2-oxa-1,3-diazol-4-yl)amino)-2-deoxyglucose (2-NBDG) was obtained from Thermo Fisher Scientific, Inc. Phlorizin was purchased from Tocris Bioscience. All other chemicals with high purity were obtained from commercial sources.

CBE extract preparation, purification and qualification. Coffea arabica beans were kindly provided by Hillkoff, and a voucher specimen (no. NU003806) was deposited at the herbarium of the Faculty of Biology, Naresuan University, Phitsanulok, Thailand. Dried Coffea arabica beans were weighed and blended thoroughly, followed by $100^{\circ} \mathrm{C}$ water infusion for $30 \mathrm{~min}$. Subsequently, the liquid extract was filtered through filter paper (Whatman plc; GE Healthcare Life Sciences) three times. The filtrate was evaporated using a lyophilizer (Labconco). The chemical constituents of CBE, caffeine, chlorogenic acid, caffeic acid and ferulic acid (Sigma-Aldrich; Merck KGaA), were used as references for validation and quantitation by high-performance liquid chromatography (HPLC) with diode array detection on an Agilent 1200 series chromatograph (LabX) at the Science and Technology Service Centre, Faculty of Science, Chiang Mai University (Chiang Mai, Thailand) according to the ISO/IEC 17025 method (International Organization for Standardization, 2005) (15). The flow rate was $0.5 \mathrm{ml} / \mathrm{min}$. The mobile phase was a binary solvent system consisting of $2 \%$ acetic acid dissolved in HPLC water (solvent A) and absolute methanol (solvent B). The column used was an Eclipse XDB-C18 (4.6x150 mm; $5 \mu \mathrm{m})$ and the absorption wavelength selected was $280 \mathrm{~nm}$.

Cell culture. The Caco-2 human colorectal adenocarcinoma cell line was purchased from American Type Culture Collection. Cells in the 2nd-22nd passage were grown in DMEM/F12 containing 20 and $1 \%$ penicillin-streptomycin in a humidified atmosphere with 5\% CO2. Caco-2 cells were seeded in 24- and 96-well plates at a density of $5 \times 10^{4}$ cells/well and were cultured at $37^{\circ} \mathrm{C}$ for $18-21$ days to create a differentiated Caco- 2 monolayer. Differentiated Caco-2 monolayer forms a continuous barrier between the apical and basolateral compartments and express several morphological and functional characteristics of the absorptive enterocytes as found in the small intestine (16). The medium was replaced every 3 days during culture.
Glucose transport in human intestinal Caco-2 cells. Differentiated Caco-2 cells were washed three times with PBS (pH 7.4) and incubated with $2 \mathrm{mM}$ 2-NBDG in the presence or absence of $0.1-1,000 \mu \mathrm{g} / \mathrm{ml} \mathrm{CBE}$, a molar ratio of four major active compounds of chlorogenic acid $(29.62 \mu \mathrm{g} / \mathrm{ml})$, caffeine $(5.11 \mu \mathrm{g} / \mathrm{ml})$, caffeic acid $(3.16 \mu \mathrm{g} / \mathrm{ml})$, ferulic acid $(1.54 \mu \mathrm{g} / \mathrm{ml})$, phlorizin $(0.5 \mathrm{mM})$ and phloretin $(1 \mathrm{mM})$ for $4 \mathrm{~h}$. The medium was removed and the cells were washed three times with ice-cold PBS. The fluorescence intensity was measured using a Synergy ${ }^{\mathrm{TM}}$ HT microplate reader (BioTek Instruments, Inc.) at excitation and emission wavelengths of 485 and $535 \mathrm{~nm}$, respectively.

Determination of cell viability. The viability of Caco-2 cells after exposure to $\mathrm{CBE}$ and other test compounds was determined using an MTT assay. Caco-2 cells were seeded at a density of $5 \times 10^{4}$ cells/well in 96-well plates and cultured for 18-21 days at $37^{\circ} \mathrm{C}$. On the day of the experiment, culture medium with or without test compounds was added and the cells were incubated for $4 \mathrm{~h}$ at $37^{\circ} \mathrm{C}$. After exposure, the cells were washed with PBS, culture medium containing MTT reagent was added and the cells were incubated for the next $4 \mathrm{~h}$ at $37^{\circ} \mathrm{C}$. At the end of the experiment, the MTT solution was aspirated and the cells were washed once with ice-cold PBS. DMSO was added to each well, and cells were incubated for a further $30 \mathrm{~min}$ at $37^{\circ} \mathrm{C}$. The absorbance of dissolved formazan was measured at a wavelength of $570 \mathrm{~nm}$ using an M965 AccuReader microplate reader (Metertech, Inc.). The sample detected at a wavelength of $680 \mathrm{~nm}$ was also used as a reference.

Inhibition of disaccharidase activity in Caco-2 cells. The dose of $\mathrm{CBE}$ used in this experiment was inferred from the glucose transport experiment, which revealed that $\mathrm{CBE}$ at a dose of $100 \mu \mathrm{g} / \mathrm{ml}$ reduced glucose transport to a similar extent to that observed with CBE at a dose of $1,000 \mu \mathrm{g} / \mathrm{ml}$. Therefore, $\mathrm{CBE}$ at a dose of $100 \mu \mathrm{g} / \mathrm{ml}$ was selected for further experiments. Inhibition of sucrase enzyme activity was determined as previously described, with some modifications (17). Briefly, differentiated Caco-2 cells were rinsed three times with Hank's balanced salt solution (HBSS) (Sigma-Aldrich; Merck KGaA). The cells were subsequently incubated with HBSS containing $28 \mathrm{mM}$ sucrose, which is an $\alpha$-glucosidase substrate, in the presence or absence of $100 \mu \mathrm{g} / \mathrm{ml} \mathrm{CBE}$, a molar ratio of four major active compounds of CBE at $100 \mu \mathrm{g} / \mathrm{ml}$ of chlorogenic acid $(29.62 \mu \mathrm{g} / \mathrm{ml})$, caffeine $(5.11 \mu \mathrm{g} / \mathrm{ml})$, caffeic acid $(3.16 \mu \mathrm{g} / \mathrm{ml})$, ferulic acid $(1.54 \mu \mathrm{g} / \mathrm{ml})$ and acarbose, disaccharidase inhibitor $(50 \mu \mathrm{M})$ at $37^{\circ} \mathrm{C}$ for $40 \mathrm{~min}$. After incubation, the incubated solution was collected. The glucose concentration was assayed using commercial enzymatic assay kits (cat. no. BLT0002) obtained from Biotechnical, Co., Ltd. Cells were lysed by three freeze-thaw cycles and protein concentration was determined using a Bradford assay (Bio-Rad Laboratories, Inc.). The data obtained are expressed as units per mg protein.

Reverse transcription-quantitative PCR (RT-qPCR). Previous studies have demonstrated that sterol regulatory element-binding protein-1 (SREBP-1c) and hepatocyte nuclear factor $1 \alpha$ $(\mathrm{HNF} 1 \alpha)$ are involved in SGLT1 and GLUT2 expression and function. Therefore, the present study measured SREBP-1c and HNF1 $\alpha$ mRNA expression in Caco- 2 cells after $4 \mathrm{~h}$ of exposure to CBE and other test compounds. Total RNA was extracted 


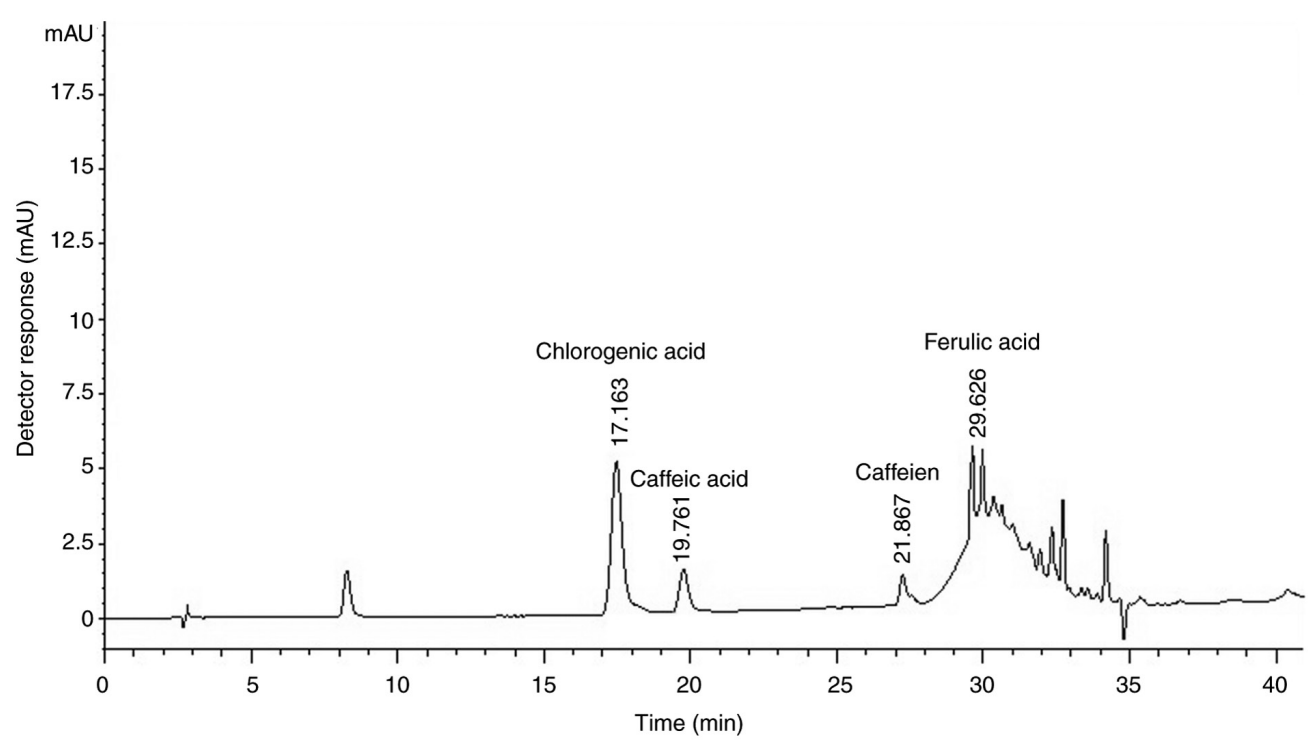

Figure 1. Representative high-performance liquid chromatography chromatogram of Coffea arabica bean extract at an absorption wavelength of $280 \mathrm{~nm}$. mAU, milli-arbitrary units.

and purified from Caco-2 cells using TRIzol ${ }^{\circledR}$ reagent (Thermo Fisher Scientific, Inc.) according to the manufacturer's protocol. First strand cDNA was synthesized using a SensiFAST ${ }^{\mathrm{TM}}$ cDNA synthesis kit (Bioline; Meridian Bioscience) and qPCR was performed using SYBR Real-Time PCR MasterMix (Bioline; Meridian Bioscience) on a CFX Touch real-time PCR system (Bio-Rad Laboratories, Inc.). PCR amplifications were performed in a $20-\mu 1$ volume with the following thermocycling conditions: A polymerase enzyme activation step at $95^{\circ} \mathrm{C}$ for $2 \mathrm{~min}$; followed by 40 cycles consisting of $5 \mathrm{sec}$ of denaturation at $95^{\circ} \mathrm{C}, 10 \mathrm{sec}$ of annealing at $60^{\circ} \mathrm{C}$ depending on primers, and $10 \mathrm{sec}$ of elongation at $72^{\circ} \mathrm{C}$. Forward and reverse primers were purchased from Macrogen, Inc. and used at a final concentration of $0.4 \mu \mathrm{M}$. The specific primer sets for human SREBP-1c, HNF1 $\alpha$ and GAPDH were as follows: Human (h)SREBP-1c forward, 5'-ATACCACCAGCGTCTACC-3' and reverse, 5'-CACCAACAGCCCATTGAG-3'; hHNF1 $\alpha$ forward, 5'-TACACCTGGTACGTCCGCAA-3' and reverse, 5'-CACTTGAAACGGTTCCTCCG-3'; and hGAPDH forward, 5'-AGCCTTCTCCATGGTGGTGAAGAC-3' and reverse, 5'-CGGAGTCAACGGATTTGGTCG-3'. The results were calculated using the $2^{-\Delta \Delta \mathrm{Cq}}$ method (18), normalized to GAPDH mRNA levels and reported as the relative fold change. qPCR amplification was performed in duplicate for each synthesized cDNA set.

Subcellular fractionation and western blot analysis. To measure protein expression of the glucose transporters SGLT1, GLUT2, AMPK and phosphorylated AMPK (p-AMPK), which is the SGLT1 and GLUT2 regulator $(19,20)$, subcellular fractions were prepared using differential centrifugation. Caco-2 cells were lysed using lysis buffer containing $1 \%$ complete protease inhibitor mixture according to the manufacturer's protocol. Briefly, samples were disrupted using a homogenizer and centrifuged at $5,000 \mathrm{x} \mathrm{g}$ for $10 \mathrm{~min}$ at $4^{\circ} \mathrm{C}$. The supernatant was designated as whole-cell lysate. Half of the supernatant was recentrifuged at $100,000 \times \mathrm{g}$ for $2 \mathrm{~h}$ at $4^{\circ} \mathrm{C}$. The supernatant fraction from this step was designated as the cytosolic fraction, while the pellet was re-suspended with the same buffer and used as the membrane fraction. The protein concentration in each sample was also determined using a Bradford assay (Bio-Rad Laboratories, Inc.), and the samples were stored at $-80^{\circ} \mathrm{C}$ prior to use. For western blot analysis, samples were resolved in $4 \mathrm{X}$ Laemmli solution, electrophoresed by 10\% SDS-PAGE and transferred onto PVDF membranes (Merck KGaA). Non-specific binding was eliminated by blocking with $5 \%(\mathrm{w} / \mathrm{v})$ non-fat dry milk in $0.05 \%$ Tween-20 in Tris-buffered saline (TBS-T) for $1 \mathrm{~h}$ at room temperature and incubated overnight at $4^{\circ} \mathrm{C}$ with polyclonal anti-rabbit SGLT1 (1:250; cat. no. 07-1417), polyclonal anti-rabbit GLUT2 (1:250; cat. no. 07-1402-I), polyclonal anti-rabbit AMPK (1:250; cat. no. 07-1417), polyclonal anti-rabbit p-AMPK (1:250; cat. no. 07-363), monoclonal anti-mouse ALP (BBM marker) (1:500; cat. no. NB110-3638), monoclonal anti-mouse $\mathrm{Na}+\mathrm{K}+\mathrm{ATPase}$ (BLM marker) (1:500; cat. no. NB300-146) or anti-mouse $\beta$-actin (1:500; cat. no. ab8224) antibodies. The PVDF membrane was washed with TBS-T buffer and incubated with horseradish peroxidase-conjugated ImmunoPure secondary goat anti-rabbit or anti-mouse IgG (1:1,000 dilution; cat. no. AP132P; Merck KGaA) for $1 \mathrm{~h}$ at room temperature. Proteins were detected using Clarity Western ECL Substrate (Bio-Rad Laboratories, Inc.) and semi-quantitatively analyzed using ImageJ version 1.44p (National Institutes of Health).

Statistical analysis. Data are presented as the mean \pm the standard error of the mean. Statistical analysis was performed using SPSS version 23 (IBM Corp.). A one-way ANOVA followed by a post-hoc Dunnett's test was used to compare differences between multiple groups. $\mathrm{P}<0.05$ was considered to indicate a statistically significant difference.

\section{Results}

Phenolic compounds in CBE. The HPLC chromatogram of CBE reliably detected chlorogenic acid, caffeine, caffeic acid and ferulic acid with retention times of 17.163, 19.761, 21.867 and $29.626 \mathrm{~min}$, respectively, compared with their respective references (Fig. 1). 

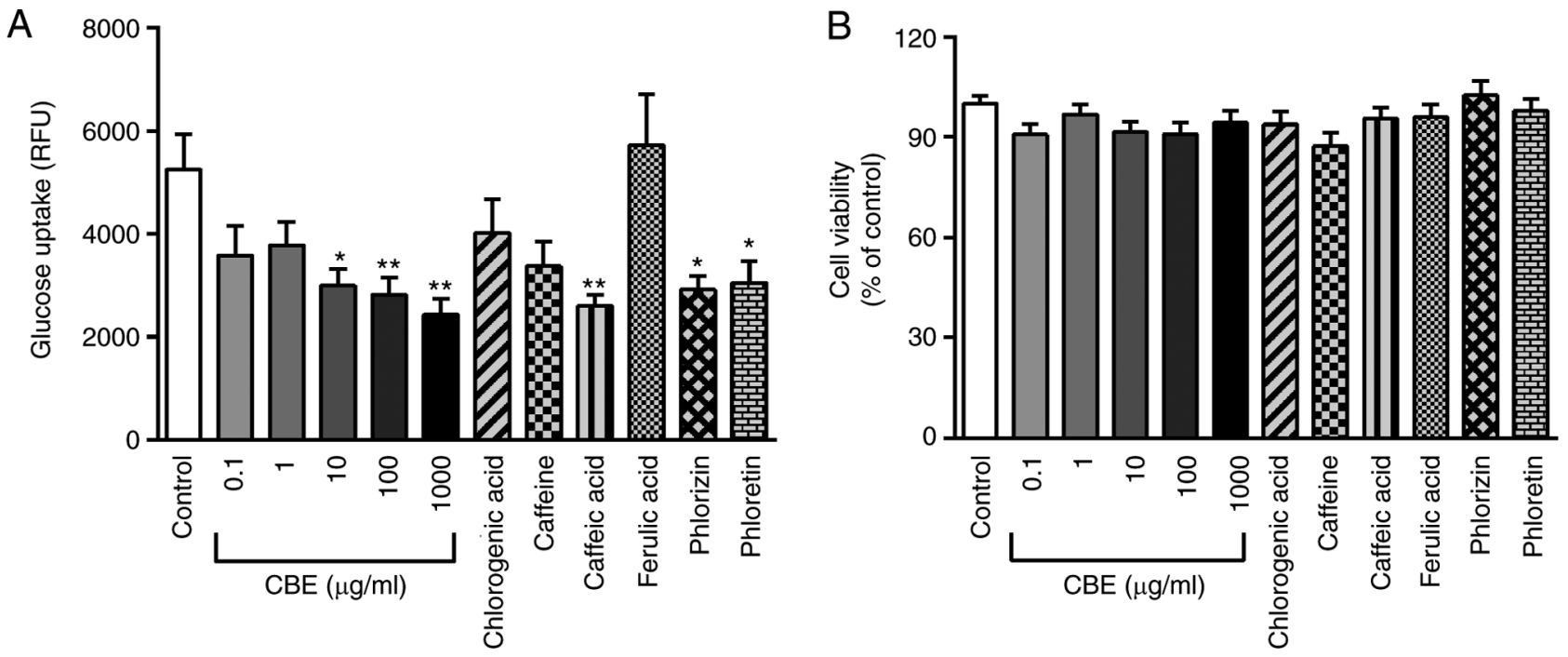

Figure 2. Effect of CBE and its constituents on glucose transport. (A) Effect of treatment with $0.1-1,000 \mu \mathrm{g} / \mathrm{ml} \mathrm{CBE}$ and its constituents at a molar ratio concentration, including chlorogenic acid $(29.62 \mu \mathrm{g} / \mathrm{ml})$, caffeine $(5.11 \mu \mathrm{g} / \mathrm{ml})$, caffeic acid $(3.16 \mu \mathrm{g} / \mathrm{ml})$, ferulic acid $(1.54 \mu \mathrm{g} / \mathrm{ml})$, as well as the SGLT1 inhibitor phlorizin $(0.5 \mathrm{mM})$ and GLUT2 inhibitor phloretin $(1 \mathrm{mM})$ for $4 \mathrm{~h}$ at $37^{\circ} \mathrm{C}$ on glucose transport. (B) Viability of Caco-2 cells after exposure to CBE, chlorogenic acid, caffeine, caffeic acid, ferulic acid, phlorizin and phloretin. Values are presented as the mean \pm the standard error of the mean $(\mathrm{n}=6)$. "P<0.05, ${ }^{* *} \mathrm{P}<0.01$ vs. control. CBE, Coffea arabica bean extract; RFUY, relative fluorescence unit.

A relatively high content of chlorogenic acid was obtained $(296.2 \mathrm{mg} / \mathrm{g})$ compared with other phenolic compounds. In addition, caffeine, a major component in Coffea arabica beans, was found at $51.1 \mathrm{mg} / \mathrm{g}$ of CBE, whereas caffeic acid and ferulic acid were present at 31.6 and $15.4 \mathrm{mg} / \mathrm{g}$ of CBE, respectively.

CBE inhibits glucose uptake in intestinal Caco-2 cells. To further demonstrate the inhibitory effect of CBE and its major constituents on glucose absorption, a glucose transport experiment was performed. As shown in Fig. 2A, CBE at $10-1,000 \mu \mathrm{g} / \mathrm{ml}$ inhibited glucose transport compared with the control similar to phlorizin (an SGLT1 inhibitor) and phloretin (a GLUT2 inhibitor). These data indicated that CBE may interfere with the transport function of SGLT1 and GLUT2 resulting in decreased glucose uptake into Caco-2 cells. In addition, the major constituent, caffeic acid, also reduced glucose uptake to a similar degree to 100 and $1,000 \mu \mathrm{g} / \mathrm{ml}$ $\mathrm{CBE}$, suggesting that inhibition of glucose uptake by CBE may be partly affected by caffeic acid.

Cell viability under exposure to test compounds was also examined. CBE $(0.1-1,000 \mu \mathrm{g} / \mathrm{ml})$, caffeine, chlorogenic acid, caffeic acid, ferulic acid, phlorizin and phloretin did not affect Caco-2 cell viability compared with that of control cells (Fig. 2B). These data suggested that $\mathrm{CBE}$ and its major components exerted an inhibitory effect on glucose absorption without any cytotoxic effect.

CBE attenuates sucrase activity in intestinal Caco- 2 cells. To determine the effect of CBE on sucrase activity, the glucose concentration in the substrate solution was evaluated. As shown in Fig. 3, co-incubation with CBE at $100 \mu \mathrm{g} / \mathrm{ml}$ decreased the glucose concentration compared with the control group. Furthermore, the constituents of CBE (caffeine, chlorogenic acid and caffeic acid) were also reduced compared with the control. The inhibitory effect was similar to that of the positive control, acarbose, which is a sucrase enzyme inhibitor.

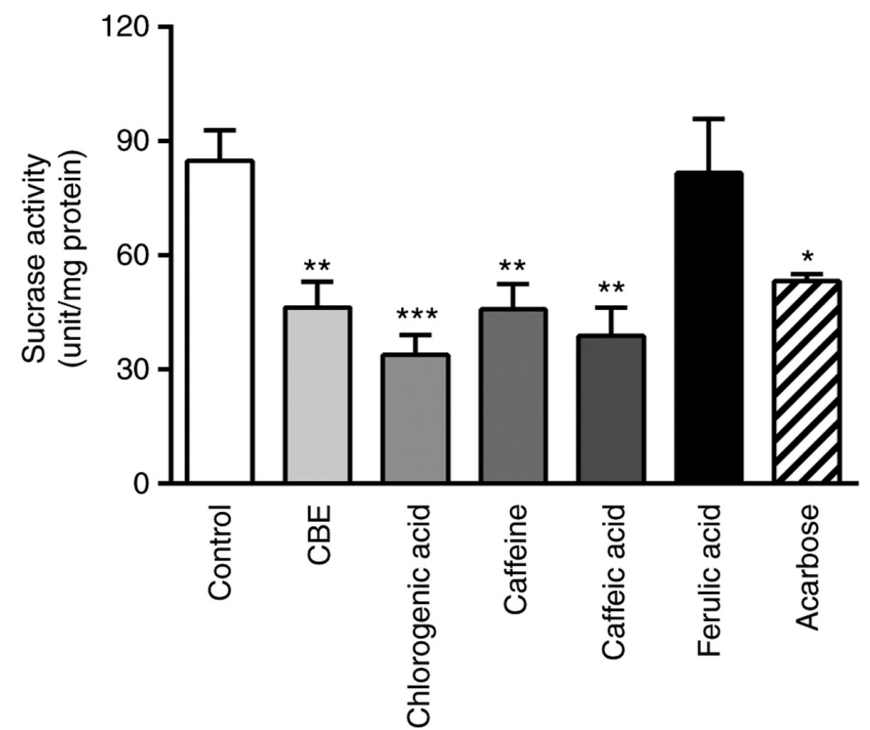

Figure 3. Effect of treatment with CBE $(100 \mu \mathrm{g} / \mathrm{ml})$, chlorogenic acid $(29.62 \mu \mathrm{g} / \mathrm{ml})$, caffeine $(5.11 \mu \mathrm{g} / \mathrm{ml})$, caffeic acid $(3.16 \mu \mathrm{g} / \mathrm{ml})$, ferulic acid $(1.54 \mu \mathrm{g} / \mathrm{ml})$ and acarbose $(50 \mu \mathrm{M})$ for $4 \mathrm{~h}$ at $37^{\circ} \mathrm{C}$, on sucrase enzyme activity. Values are presented as the mean \pm the standard error of the mean $(\mathrm{n}=6) .{ }^{*} \mathrm{P}<0.05,{ }^{* *} \mathrm{P}<0.01,{ }^{* * *} \mathrm{P}<0.001$ vs. control. CBE, Coffea arabica bean extract.

Therefore, CBE may not only reduce glucose transporter expression but also decrease disaccharidase enzyme activity, leading to decreased glucose transport across the human intestinal cell membrane.

CBE downregulates SGLT1 and GLUT2 protein expression. To further determine whether the reduced rate of glucose transport caused by CBE was due to decreased membrane expression of SGLT1, cellular protein expression of SGLT1 was determined using western blotting. As shown in Fig. 4A and B, SGLT1 membrane protein expression was decreased 

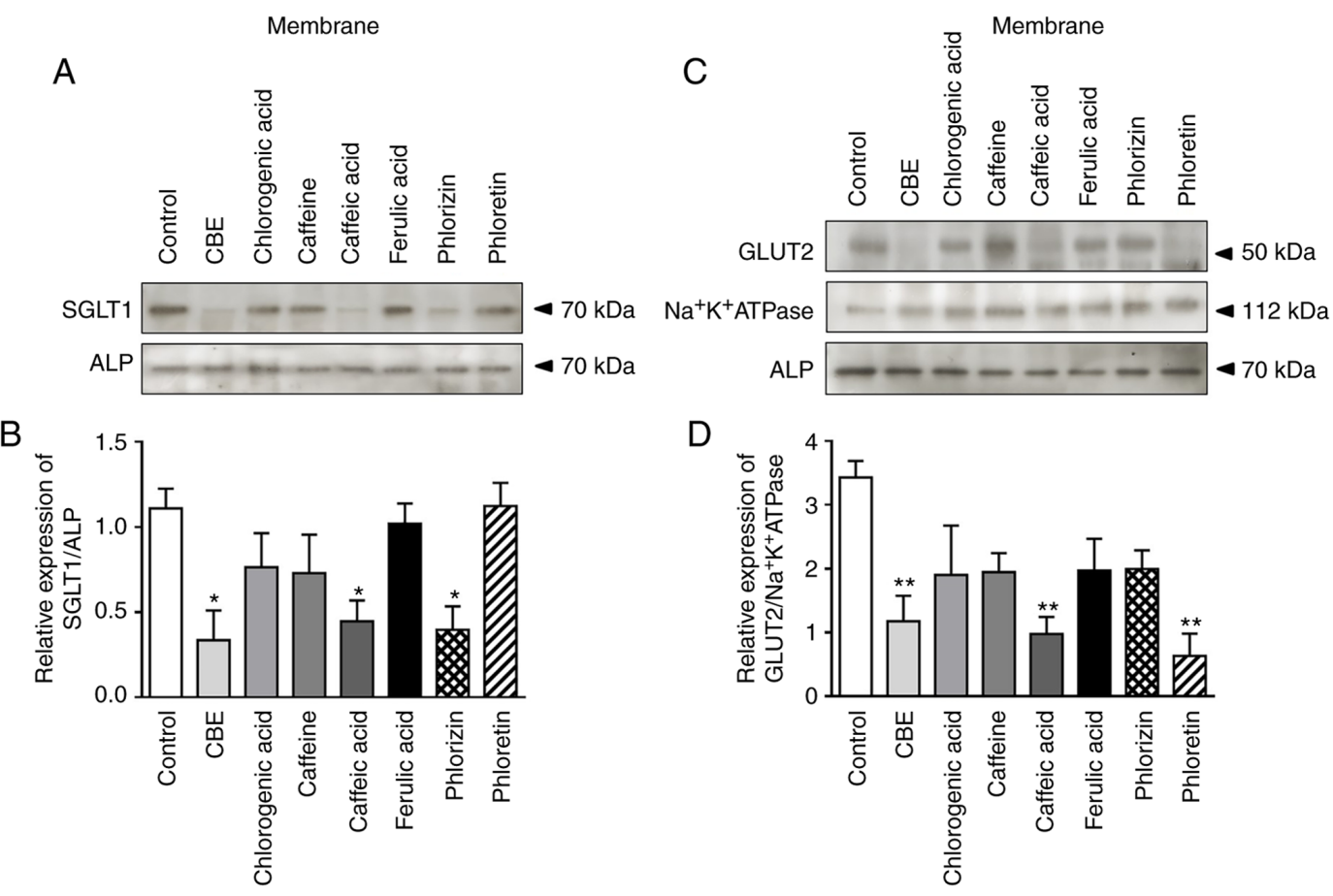

Figure 4. Effect of treatment with CBE $(100 \mu \mathrm{g} / \mathrm{ml})$, chlorogenic acid $(29.62 \mu \mathrm{g} / \mathrm{ml})$, caffeine $(5.11 \mu \mathrm{g} / \mathrm{ml})$, caffeic acid $(3.16 \mu \mathrm{g} / \mathrm{ml})$, ferulic acid (1.54 $\mu \mathrm{g} / \mathrm{ml})$, phlorizin $(0.5 \mathrm{mM})$ and phloretin $(1 \mathrm{mM})$, for $4 \mathrm{~h}$ at $37^{\circ} \mathrm{C}$, on glucose transporters membrane protein expression. (A) Representative blot of SGLT1 membrane protein expression, (B) semi-quantification of relative SGLT1/ALP protein expression in each fraction, (C) representative blot of GLUT2 membrane protein expression and (D) semi-quantification of relative GLUT2/Na+K+ATPase protein expression in each fraction. Values are presented as the mean \pm the standard error of the mean (n=3). ${ }^{*} \mathrm{P}<0.05,{ }^{* *} \mathrm{P}<0.01$ vs. control. CBE, Coffea arabica bean extract; SGLT1, sodium glucose co-transporter 1; GLUT2 glucose transporter 2; ALP, alkaline phosphatase.

by CBE and its constituent, caffeic acid, compared with the control group. Similarly, phlorizin (an SGLT1 inhibitor) also decreased SGLT1 protein expression in Caco-2 cells, whereas cells treated with caffeine, chlorogenic acid, ferulic acid and phloretin did not exhibit any notable differences. Accordingly, CBE-induced downregulation of SGLT1 membrane protein expression resulted in a reduction of glucose uptake in human intestinal epithelia.

As mentioned above, GLUT2 is also associated with intestinal glucose absorption in both the BBM and BLM. Therefore, the present study further examined the effect of CBE on GLUT2 expression using western blotting. The results showed that GLUT2 membrane protein expression was reduced by CBE, caffeic acid and phloretin (a GLUT2 inhibitor) (Fig. 4C and D). However, caffeine-, chlorogenic acid-, ferulic acid- and phlorizin-treated cells did not exhibit any notable differences (Fig. 4B). Therefore, the results suggested that $\mathrm{CBE}$ downregulated glucose transport across the jejunal epithelial cell membrane via GLUT2 inhibition.

CBE inhibits SGLT1 expression via activation of AMPK. To further elucidate the mechanism by which $\mathrm{CBE}$ reduced glucose uptake, the effect of CBE on intestinal AMPK activation and expression was further investigated. As shown in Fig. 5, phosphorylation of AMPK, a rate-limiting enzyme decelerating gluconeogenesis, was increased in the CBE-treated group compared with the control group, similar to the caffeic acid-treated group. Neither CBE constituents nor glucose transporter inhibitors activated p-AMPK. Therefore, $\mathrm{CBE}$ and caffeic acid exerted a suppressive effect on glucose absorption, primarily via inhibition of SGLT1 expression
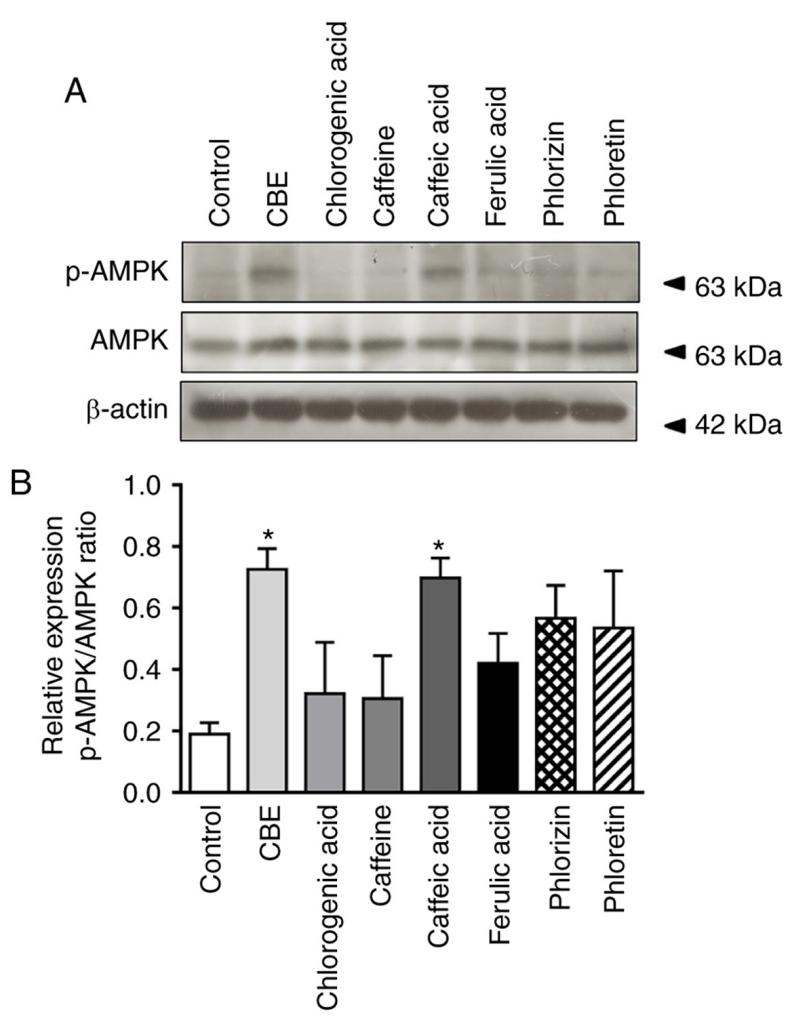

Figure 5. Effect of treatment with CBE $(100 \mu \mathrm{g} / \mathrm{ml})$, chlorogenic acid $(29.62 \mu \mathrm{g} / \mathrm{ml})$, caffeine $(5.11 \mu \mathrm{g} / \mathrm{ml})$, caffeic acid $(3.16 \mu \mathrm{g} / \mathrm{ml})$, ferulic acid $(1.54 \mu \mathrm{g} / \mathrm{ml})$, phlorizin $(0.5 \mathrm{mM})$ and phloretin $(1 \mathrm{mM})$, for $4 \mathrm{~h}$ at $37^{\circ} \mathrm{C}$ on AMPK protein expression. (A) Representative blot of AMPK membrane protein expression and (B) semi-quantification of relative AMPK/ $\beta$-actin protein expression in each fraction. Values are presented as the mean \pm the standard error of the mean $(\mathrm{n}=3) .{ }^{*} \mathrm{P}<0.05$ vs. control. CBE, Coffea arabica bean extract; p-, phospho; AMPK, 5-AMP-activated protein kinase. 


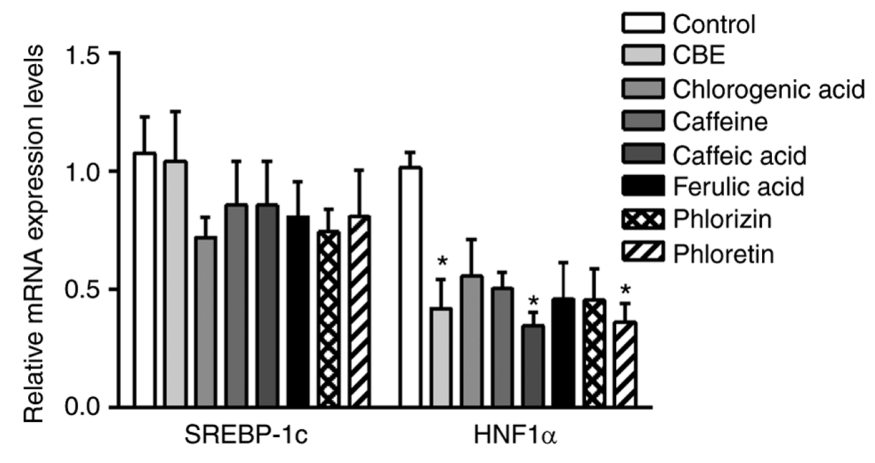

Figure 6. mRNA expression levels of glucose transporter regulator genes, including SREBP-1c and HNF1 $\alpha$, in Caco-2 cells treated with CBE $(100 \mu \mathrm{g} / \mathrm{ml})$ and its constituents at a molar ratio concentration, including chlorogenic acid $(29.62 \mu \mathrm{g} / \mathrm{ml})$, caffeine $(5.11 \mu \mathrm{g} / \mathrm{ml})$, caffeic acid $(3.16 \mu \mathrm{g} / \mathrm{ml})$, ferulic acid $(1.54 \mu \mathrm{g} / \mathrm{ml})$, phlorizin $(0.5 \mathrm{mM})$ or phloretin $(1 \mathrm{mM})$, for $4 \mathrm{~h}$ at $37^{\circ} \mathrm{C}$. Values are presented as the mean \pm the standard error of the mean $(n=5)$. ${ }^{*} \mathrm{P}<0.05$ vs. control. CBE, Coffea arabica bean extract; SREBP-1c, sterol regulatory element binding protein-1c; $H N F 1 \alpha$, hepatocyte nuclear factor $1 \alpha$.

at the translational level, resulting in modulation of AMPK activity.

CBE modulates GLUT2 expression through HNFla gene suppression. The present study further investigated the mechanisms by which CBE inhibited glucose uptake. SREBP-1c and HNF1 $\alpha$ serve a critical role in glucose transporter regulation. Therefore, the expression levels of these transcription factors in Caco- 2 cells were determined using qPCR. CBE at $100 \mu \mathrm{g} / \mathrm{ml}$ suppressed HNF1 $\alpha$ mRNA expression, similar to caffeic acid and phloretin, a GLUT2 inhibitor (Fig. 6). However, there was no effect on SREBP-1c expression. Therefore, these data suggested that $\mathrm{CBE}$ and its major component, caffeic acid, had an inhibitory effect on GLUT2 transport function and expression via $\mathrm{HNF} 1 \alpha$ expression.

\section{Discussion}

It has been previously shown that the diabetic status enhances intestinal glucose transport across the BBM and BLM by increasing SGLT1 and GLUT2 function and expression at both the transcriptional and translational level (4,21-23). In addition, the amount of SGLT1 protein is upregulated four-fold in the gut of patients with type 2 diabetes mellitus, resulting in a three-fold elevation of monosaccharide absorption compared with healthy individuals (24). Therefore, the identification of novel strategies to modulate these key regulators in glucose absorption may be useful for preventing further development of diabetes mellitus. A reduction of cellular glucose transport indicates decreased cell surface glucose transporter expression or interference in glucose transporter trafficking. The results of the present study demonstrated that $\mathrm{CBE}$ and one of its constituents, caffeic acid, inhibited SGLT1 and GLUT2 membrane expression, resulting in reduced glucose absorption. Similarly, a reduction of glucose uptake into enterocytes has been reported in SGLT1-deficient mice (25). Furthermore, several natural compounds, including flavonoids, anthocyanin-rich berry extract and polyphenol-rich herbal extract, also inhibit glucose absorption via downregulation of SGLT1 and GLUT2 expression (26-28).
AMPK serves a role in the regulation of cellular glucose uptake, glycolysis, fatty acid oxidation and enzymes required for ATP production (29-32). Previous studies have demonstrated that AMPK regulates cellular glucose uptake through the increased translocation of GLUT2 to the BBM $(20,33)$, whereas another study suggested that AMPK decreases cellular glucose uptake by reducing the expression levels of SGLT1 in cell membranes (20). Consistent with the effect of CBE on AMPK activation in the present study, caffeic acid, one of the major components found in $\mathrm{CBE}$, also stimulates AMPK in Caco-2 cells, resulting in downregulation of SGLT1. Furthermore, CBE and caffeic acid suppress GLUT2 protein expression, resulting in reduced glucose uptake, suggesting that $\mathrm{CBE}$ and caffeic acid may regulate GLUT2 protein expression. Although the direct effect of CBE on AMPK activation was not investigated in the present study, a previous study demonstrated that caffeic acid directly activates AMPK in C-4I cells, whereas chlorogenic acid does not cause AMPK stimulation $(34,35)$. Therefore, CBE, primarily caffeic acid, inhibits intestinal glucose absorption, partly via activation of AMPK-mediated downregulation of SGLT1/GLUT2 expression.

A previous study showed that HNF1 $\alpha$ is an important transcription factor for endogenous SGLT1 expression in cultured enterocytes (36). Additionally, HNF1 $\alpha$ is essential for the expression of GLUT2 transporter $(37,38)$. Consistently, the present study demonstrated that $\mathrm{CBE}$, caffeic acid and the GLUT2 inhibitor phloretin downregulated HNF1 $\alpha$ mRNA expression, resulting in reduction of glucose transporter expression and function. Similarly, SGLT1 expression is reduced following HNF1 $\alpha$ - or hepatocyte nuclear factor-1 $\beta$-knockdown (36). Furthermore, GLUT2 expression is decreased in HNF1 $\alpha^{-/-}$mice (39) and INS1 cells expressing a dominant negative inhibitor of HNF1 $\alpha$ (38). Therefore, downregulating intestinal SGLT1 and GLUT2 expression via AMPK protein activation and HNF1 $\alpha$ gene suppression by $\mathrm{CBE}$ contributes to reduced transepithelial transport of glucose in the intestinal epithelium.

CBE and its constituents (caffeine, chlorogenic acid and caffeic acid) strongly inhibit sucrase activity in Caco-2 cells, similar to acarbose (a sucrase enzyme inhibitor). Similarly, the mulberry leaf polyphenols arabinoxylan monosaccharide and arabinoxylan oligosaccharide markedly decrease intestinal $\alpha$-glucosidase enzyme activity, making glucose unavailable for absorption $(40,41)$. Therefore, CBE downregulated glucose transporter expression, and as a result, reduced glucose uptake into intestinal absorptive cells. Furthermore, CBE interfered with disaccharidase enzyme activity. Due to this distinctive mechanism of glucose inhibition, CBE may be a novel glucose-lowering supplement, broadening the available therapeutic options for diabetes mellitus. However, it should be noted that the effect of CBE on intestinal glucose absorption and its mechanisms require further investigation in animal models and clinical trials.

In conclusion, to the best of our knowledge, the present study is the first to demonstrate the effective antihyperglycemic action of CBE by reducing intestinal glucose absorption via activation of AMPK, suppressing HNF1 $\alpha$ gene expression, downregulating SGLT1 and GLUT2 expression and function, and interfering with sucrase enzyme activity (Fig. 7). Therefore, CBE may hold promise as an intestinal glucose 


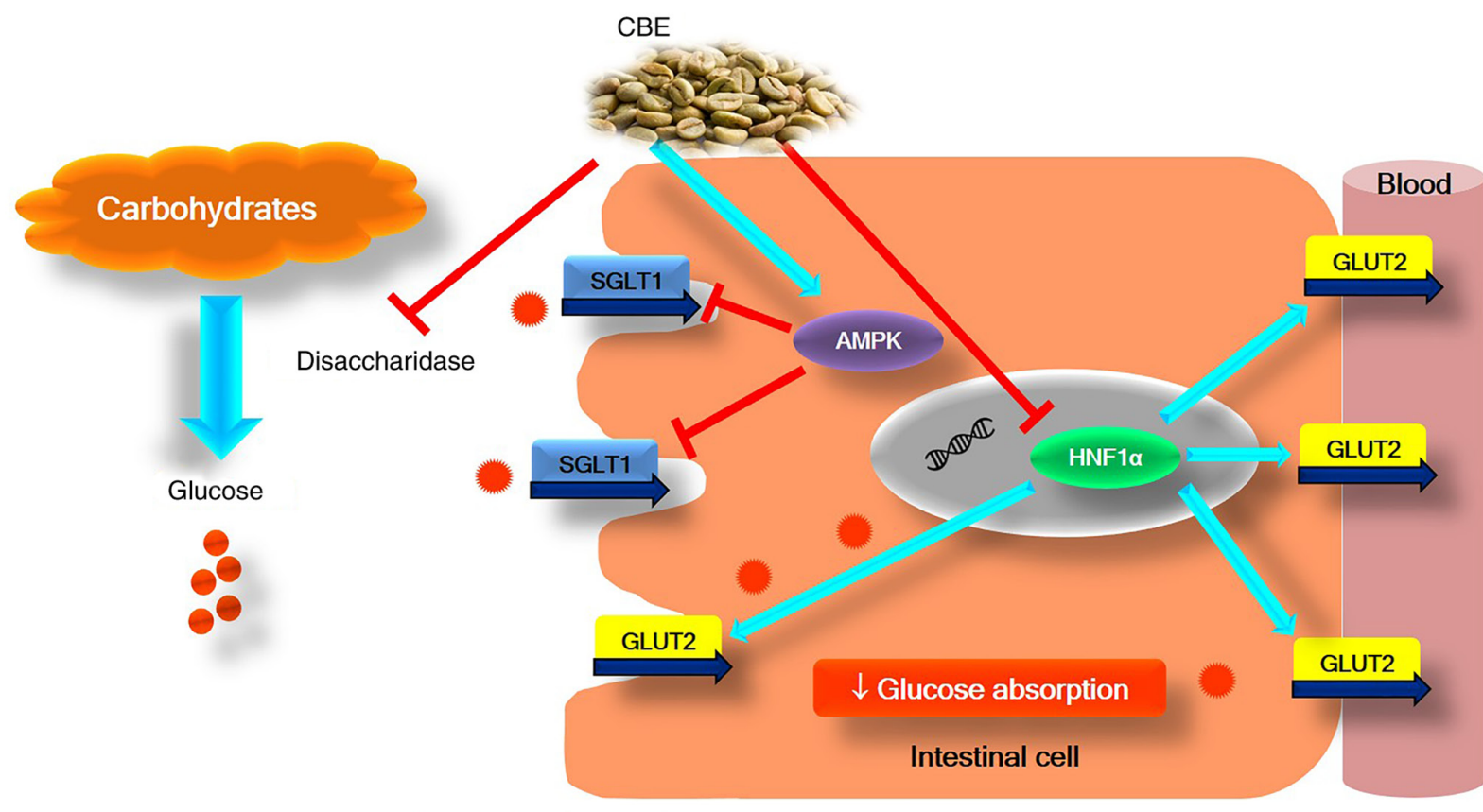

Brush border membrane

Basolateral membrane

Figure 7. Inhibitory effects of CBE on glucose transport and its mechanisms. CBE, Coffea arabica bean extract. SGLT1, sodium glucose co-transporter 1; GLUT2 glucose transporter 2; HNF1 $\alpha$, hepatocyte nuclear factor 1 $\alpha$;AMPK, 5-AMP-activated protein kinase.

absorption inhibitor, and further in vivo studies and clinical trials are required to elucidate whether CBE has an overall antihyperglycemic effect in diabetes mellitus.

\section{Acknowledgements}

The authors would like to thank Mr Jakkapong Inchai (Department of Physiology, Faculty of Medicine, Chiang Mai University) for his technical assistance.

\section{Funding}

The present study was supported by funding from the Unit of Excellent in Research and Product Development of Coffee, University of Phayao (grant nos. UoE62007 and UoE63004), the School of Medical Science, University of Phayao, Phayao, Thailand (grant no. 631009) and the National Higher Education Science Research and Innovation Policy Council (grant no. FF64-RIB008).

\section{Availability of data and materials}

All data generated and/or analyzed during the present study are included in the published article.

\section{Authors' contributions}

AO was involved in conceptualization, methodology, validation, investigation, writing the original draft, visualization, supervision and project administration. AD was involved in designing the methodology, and reviewing and editing of the manuscript. CS was involved in designing the methodology, and in reviewing, editing and revising of the manuscript. All authors have read and approved the final manuscript. AO, AD and CS confirm the authenticity of all the raw data.

\section{Ethics approval and consent to participate}

Not applicable.

\section{Patient consent for publication}

Not applicable.

\section{Competing interests}

The authors declare that they have no competing interests.

\section{References}

1. Wright EM, Loo DD and Hirayama BA: Biology of human sodium glucose transporters. Physiol Rev 91: 733-794, 2011.

2. Wolffram S, Blöck M and Ader P: Quercetin-3-glucoside is transported by the glucose carrier SGLT1 across the brush border membrane of rat small intestine. J Nutr 132: 630-635, 2002.

3. Yoshikawa T, Inoue R, Matsumoto M, Yajima T, Ushida K and Iwanaga T: Comparative expression of hexose transporters (SGLT1, GLUT1, GLUT2 and GLUT5) throughout the mouse gastrointestinal tract. Histochem Cell Biol 135: 183-194, 2011.

4. Miyamoto K, Hase K, Taketani Y, Minami H, Oka T, Nakabou Y and Hagihira $\mathrm{H}$ : Diabetes and glucose transporter gene expression in rat small intestine. Biochem Biophys Res Commun 181: 1110-1117, 1991.

5. Ogata H, Seino Y, Harada N, Iida A, Suzuki K, Izumoto T, Ishikawa K, Uenishi E, Ozaki N, Hayashi Y, et al: KATP channel as well as SGLT1 participates in GIP secretion in the diabetic state. J Endocrinol 222: 191-200, 2014.

6. Fujita Y, Kojima H, Hidaka H, Fujimiya M, Kashiwagi A and Kikkawa R: Increased intestinal glucose absorption and postprandial hyperglycaemia at the early step of glucose intolerance in Otsuka Long-Evans Tokushima Fatty rats. Diabetologia 41: 1459-1466, 1998 
7. Dyer J, Wood IS, Palejwala A, Ellis A and Shirazi-Beechey SP Expression of monosaccharide transporters in intestine of diabetic humans. Am J Physiol Gastrointest Liver Physiol 282: G241-G248, 2002.

8. Corpe CP, Basaleh MM, Affleck J, Gould G, Jess TJ and Kellett GL: The regulation of GLUT5 and GLUT2 activity in the adaptation of intestinal brush-border fructose transport in diabetes. Pflugers Arch 432: 192-201, 1996.

9. Kellett GL and Helliwell PA: The diffusive component of intestinal glucose absorption is mediated by the glucose-induced recruitment of GLUT2 to the brush-border membrane. Biochem J 350: 155-162, 2000.

10. Dharmananda S: Medicine IfT: Coffee in China and the Analysis of Coffee According to Traditional Chinese Medicine. ITM, Portland, OR, 2003.

11. Nuhu AA: Bioactive micronutrients in coffee: Recent analytical approaches for characterization and quantification. ISRN Nutr 2014: 384230, 2014.

12. Miran J: Guest Editor's Introduction: Space, Mobility, and Translocal Connections across the Red Sea Area since 1500 Northeast Afr Stud 12: ix-xxvi, 2012.

13. Oliveira AL, Cabral FA, Eberlin MN and Cordello HM: Sensory evaluation of black instant coffee beverage with some volatile compounds present in aromatic oil from roasted coffee. Food Sci Technol (Campinas) 29: 76-80, 2009.

14. Salinardi TC, Rubin KH, Black RM and St-Onge MP: Coffee mannooligosaccharides, consumed as part of a free-living, weight-maintaining diet, increase the proportional reduction in body volume in overweight men. J Nutr 140: 1943-1948, 2010.

15. International Organization for Standardization: ISO/IEC 17025 General requirements for the competence of testing and calibration laboratories. International Standard ISO/IEC 17025, pp1-39, 2005.

16. Verhoeckx K, Cotter P, López-Expósito I, Kleiveland C, Lea T, Mackie A, Requena T, Swiatecka D and Wichers H (eds): Caco-2 Cell Line. In: The Impact of Food Bioactives on Health. Springer, Cham, 2015.

17. Pan GY, Huang ZJ, Wang GJ, Fawcett JP, Liu XD, Zhao XC Sun JG and Xie YY: The antihyperglycaemic activity of berberine arises from a decrease of glucose absorption. Planta Med 69: 632-636, 2003

18. Livak KJ and Schmittgen TD: Analysis of relative gene expression data using real-time quantitative PCR and the 2(-Delta Delta C(T)) Method. Methods 25: 402-408, 2001.

19. Sopjani M, Bhavsar SK, Fraser S, Kemp BE, Föller M and Lang F: Regulation of $\mathrm{Na}^{+}$-coupled glucose carrier SGLT1 by AMP-activated protein kinase. Mol Membr Biol 27: 137-144, 2010.

20. Walker J, Jijon HB, Diaz H, Salehi P, Churchill T and Madsen KL: 5-aminoimidazole-4-carboxamide riboside (AICAR) enhances GLUT2-dependent jejunal glucose transport: A possible role for AMPK. Biochem J 385: 485-491, 2005.

21. Debnam ES, Ebrahim HY and Swaine DJ: Diabetes mellitus and sugar transport across the brush-border and basolatera membranes of rat jejunal enterocytes. J Physiol 424: 13-25, 1990

22. Fedorak RN, Cheeseman CI, Thomson AB and Porter VM Altered glucose carrier expression: Mechanism of intestinal adaptation during streptozocin-induced diabetes in rats. Am J Physiol 261: G585-G591, 1991.

23. Miyamoto K, Takagi T, Fujii T, Matsubara T, Hase K, Taketani Y, Oka T, Minami H and Nakabou Y: Role of liver-type glucose transporter (GLUT2) in transport across the basolateral membrane in rat jejunum. FEBS Lett 314: 466-470, 1992.

24. Williamson G: Possible effects of dietary polyphenols on sugar absorption and digestion. Mol Nutr Food Res 57: 48-57, 2013.

25. Röder PV, Geillinger KE, Zietek TS, Thorens B, Koepsell H and Daniel H: The role of SGLT1 and GLUT2 in intestinal glucose transport and sensing. PLoS One 9: e89977, 2014.

26. Alzaid F, Cheung HM, Preedy VR and Sharp PA: Regulation of glucose transporter expression in human intestinal Caco-2 cells following exposure to an anthocyanin-rich berry extract. PLoS One 8: e78932, 2013.
27. Farrell TL, Ellam SL, Forrelli T and Williamson G: Attenuation of glucose transport across Caco-2 cell monolayers by a polyphenol-rich herbal extract: Interactions with SGLT1 and GLUT2 transporters. Biofactors 39: 448-456, 2013.

28. Kwon O, Eck P, Chen S, Corpe CP, Lee JH, Kruhlak M and Levine M: Inhibition of the intestinal glucose transporter GLUT2 by flavonoids. FASEB J 21: 366-377, 2007.

29. Carling D: The role of the AMP-activated protein kinase in the regulation of energy homeostasis. Novartis Found Symp 286 72-85, 162-163, 196-203, 2007.

30. Horie T, Ono K, Nagao K, Nishi H, Kinoshita M, Kawamura T, Wada H, Shimatsu A, Kita T and Hasegawa K: Oxidative stress induces GLUT4 translocation by activation of PI3-K/Akt and dual AMPK kinase in cardiac myocytes. J Cell Physiol 215 : 733-742, 2008

31. Jensen TE, Rose AJ, Hellsten Y, Wojtaszewski JF and Richter EA: Caffeine-induced $\mathrm{Ca}(2+)$ release increases AMPK-dependent glucose uptake in rodent soleus muscle. Am J Physiol Endocrinol Metab 293: E286-E292, 2007.

32. Winder WW and Thomson DM: Cellular energy sensing and signaling by AMP-activated protein kinase. Cell Biochem Biophys 47: 332-347, 2007.

33. Gabler NK, Radcliffe JS, Spencer JD, Webel DM and Spurlock ME Feeding long-chain n-3 polyunsaturated fatty acids during gestation increases intestinal glucose absorption potentially via the acute activation of AMPK. J Nutr Biochem 20: 17-25, 2009.

34. Tsuda S, Egawa T, Ma X, Oshima R, Kurogi E and Hayashi T: Coffee polyphenol caffeic acid but not chlorogenic acid increases 5'AMP-activated protein kinase and insulin-independent glucose transport in rat skeletal muscle. J Nutr Biochem 23: 1403-1409, 2012

35. Tyszka-Czochara M, Bukowska-Strakova K, KocembaPilarczyk KA and Majka M: Caffeic acid targets AMPK signaling and regulates tricarboxylic acid cycle anaplerosis while metformin downregulates HIF-1 $\alpha$-induced glycolytic enzymes in human cervical squamous cell carcinoma lines. Nutrients 10: 841, 2018.

36. Balakrishnan A, Stearns AT, Rhoads DB, Ashley SW and Tavakkolizadeh A: Defining the transcriptional regulation of the intestinal sodium-glucose cotransporter using RNA-interference mediated gene silencing. Surgery 144: 168-173, 2008.

37. Ban N, Yamada Y, Someya Y, Miyawaki K, Ihara Y, Hosokawa M, Toyokuni S, Tsuda K and Seino Y: Hepatocyte nuclear factor-1alpha recruits the transcriptional co-activator p300 on the GLUT2 gene promoter. Diabetes 51: 1409-1418, 2002.

38. Párrizas M, Maestro MA, Boj SF, Paniagua A, Casamitjana R, Gomis R, Rivera F and Ferrer J: Hepatic nuclear factor 1-alpha directs nucleosomal hyperacetylation to its tissue-specific transcriptional targets. Mol Cell Biol 21: 3234-3243, 2001.

39. Shih DQ, Screenan S, Munoz KN, Philipson L, Pontoglio M, Yaniv M, Polonsky KS and Stoffel M: Loss of HNF-1alpha function in mice leads to abnormal expression of genes involved in pancreatic islet development and metabolism. Diabetes 50: 2472-2480, 2001

40. Li Q, Wang C, Liu F, Hu T, Shen W, Li E, Liao S and Zou Y: Mulberry leaf polyphenols attenuated postprandial glucose absorption via inhibition of disaccharidases activity and glucose transport in Caco-2 cells. Food Funct 11: 1835-1844, 2020.

41. Malunga LN, Eck P and Beta T: Inhibition of intestinal $\alpha$-glucosidase and glucose absorption by feruloylated arabinoxylan mono- and oligosaccharides from corn bran and wheat aleurone. J Nutr Metab 2016: 1932532, 2016.

This work is licensed under a Creative Commons Attribution-NonCommercial-NoDerivatives 4.0 International (CC BY-NC-ND 4.0) License. 